\title{
The Life of Fishes, by N. B. Marshall. Weidenfeld and Nicolson, 63s.
}

The modern type-face used in this book hurts one reader, but its use may have allowed the price to be so low for a big book, finely illustrated as this is by Mrs Marshall. Another discomfort comes from too many facts per paragraph-one contained eight detached facts in ten lines-but the book is successful, in that it is interesting and useful in a high degree. I do not know where else I could find a compendium on:-swimming, swimbladders, electrics, sound-production, fishes of the coral seas, of the open ocean, of continental slopes, and of the abysses. But, for several reasons, it does not supersede Norman's History.

The teleostean fishes embody a great variety of inventions: weightlessness in water allows them to be flexible, swift and supple; and to be quite still, which gives precision of aim in those with protrusible jaws. Some fishes walk and climb or hop on land. Breeding fish often claim territories, which they usually defend by warning colours and display movements, but in some species in muddy water a trespasser is perceived and warned by disturbance of an electric field. Before they go to sea, salmon and eels adjust their blood and other tissues. Teleostean fish are among the minority of vertebrate orders whose members can perceive colour. Some fish are guided by the position of the sun, but homing to a former river habitat is by smell. Many fish grunt in courting; one species purrs. Most deep-sea fishes manufacture their own light; but coastal species keep cultures of luminous bacteria, housed in dark lanterns, which the fish can open at will.

There is no end to the interest and diversity of fishes but there must be some end to a review.

MICHAEL GRAHAM

\section{Handbook of Waterfowl Behaviour, by Paul A. Johnsgard. Constable, 75s.}

Paul Johnsgard knows more about waterfowl behaviour than anyone else in the world. He has seen more species alive than Jean Delacour or Peter Scott, and has applied the methods of comparative ethology to them more thoroughly than Konrad Lorenz. As Dr Johnsgard is the first to acknowledge, he stands on the shoulders of these illustrious precursors, and so he sees more, and more clearly, than any of them. His stated aim in this book was "to provide the barest minimum of information on each species that will allow other persons to compare their observations and to develop more detailed and quantitative studies". He has succeeded brilliantly. The work is well-organised and carried through with clarity and economy, despite the problem of depicting rapid adtions in words, still photographs and drawings.

The book is indispensable to professionals, but what will other enthusiasts make of it? Probably not much. Cornell University Press made a halfhearted attempt to enter it in the glossy-bird-book market by printing the text and the author's diagrammatic drawings on creamy paper, but did not make a success of reproducing the photographs. The English publishers have put on a more striking jacket, with the letter " $u$ " inserted in "Behavior", but otherwise left the book untouched. So will the general 